\title{
Change in overweight and obesity over a decade according to sociodemographic factors in Brazilian adolescents
}

\author{
Mudança no sobrepeso e obesidade após uma década de acordo \\ com fatores sociodemográficos em adolescentes brasileiros
}

Priscila Cristina dos Santos (https://orcid.org/0000-0002-0166-1201) ${ }^{1}$

Kelly Samara da Silva (https://orcid.org/0000-0002-7356-1680) ${ }^{1}$

Jaqueline Aragoni da Silva (https://orcid.org/0000-0001-6344-9073) ${ }^{1}$

Carla Elane Silva dos Santos (https://orcid.org/0000-0002-3659-6921) ${ }^{1}$

Giovani Firpo Del Duca (https://orcid.org/0000-0003-0893-2032) ${ }^{1}$

Adair da Silva Lopes (https://orcid.org/0000-0003-2278-9076) ${ }^{1}$

Markus Vinícius Nahas (https://orcid.org/0000-0002-4378-4031) ${ }^{1}$
${ }^{1}$ Programa de PósGraduação em Educação Física, Universidade Federal de Santa Catarina. Campus Universitário Trindade. 88040-900 Florianópolis SC Brasil. prisantos.personal@ gmail.com

\begin{abstract}
The aims were to examine changes in the prevalence of overweight and obesity among students from 2001 to 2011, and to verify if these changes differ according to age group, area of residence, and family income. We analyzed two cross-sectional surveys conducted in 2001 and 2011 with brazilian adolescents. Sociodemographic and anthropometric characteristics were self-reported using a questionnaire. Multinomial logistic regression was used to analyze changes in overweight and obesity between the two surveys. The nutritional status was the outcome of the present study and the surveys (2001 and 2011) were the exposure. The odds of being overweight and obese were higher among boys and girls in urban areas in the 2011 survey compared to the 2001. Boys and girls with higher income were also more likely to present overweight and obesity in the second survey compared to the first. An increase of overweight and obesity was observed over a decade. We suggest that future interventions consider the area of residence and the family income to strengthen the effectiveness of actions developed to prevent and control these indicators among adolescents.
\end{abstract}

Key words Obesity, Adolescent, Family income, Area of residence
Resumo Os objetivos do estudo foram examinar as mudanças na prevalência de sobrepeso e obesidade entre os estudantes de 2001 a 2011 e verificar se essas alterações diferem de acordo com a faixa etária, a área de residência e a renda familiar. Analisamos dois levantamentos transversais realizados em 2001 e 2011 com adolescentes brasileiros. As características sociodemográficas e antropométricas foram autorrelatadas por meio de um questionário. Regressão logística multinomial foi utilizada para analisar as mudanças no sobrepeso e obesidade entre os dois inquéritos. O estado nutricional foi considerado o desfecho do presente estudo e os inquéritos (2001 e 2011) foram as exposições. As razões de chance de sobrepeso e obesidade foram maiores entre os meninos e meninas em áreas urbanas no inquérito de $2011 \mathrm{em}$ comparação com 2001. Meninos e meninas com maior renda também apresentaram maior chance de sobrepeso e obesidade no segundo inquérito. Sugerimos que futuras intervenções considerem a área de residência e a renda familiar para fortalecer a eficácia das ações desenvolvidas para prevenir e controlar esses indicadores entre os adolescentes.

Palavras-chave Obesidade, Adolescente, Renda, Área urbana, Área rural 


\section{Introduction}

An increasing trend in the prevalence of overweight and obesity in adolescents has been observed in many countries in the last decades ${ }^{1-6}$. Likewise, in Brazil, the National Household Budget Survey ${ }^{7}$ showed that obesity increased from $0.4 \%$ to $5.9 \%$ among boys and from $0.7 \%$ to $4.0 \%$ among girls in a period of 34 years. This scenario has become a public health concern worldwide ${ }^{8,9}$, since higher body mass index is associated with risk of obesity in adulthood ${ }^{10-12}$, and the presence of these outcomes in any of the life stages may result in negative health consequences, increasing public costs ${ }^{8}$.

Although a global increase in the prevalence of overweight and obesity in adolescents is reported $^{8,9}$, there are large variations in the behavior of these outcomes over time for specific subgroups. Wang and $\mathrm{Lim}^{8}$ mention that prevalence may vary according to area of residence, age, gender, race/ethnicity, and socio-economic status. However, there is lack of information regarding these trends in other sociodemographic subgroups $^{13}$ such as family income, which has been associated with overweight, especially in middle income countries like Brazil ${ }^{14}$.

Therefore, monitoring of overweight and obesity trends is extremely relevant for the comparison over time $\mathrm{e}^{15}$, as well as to explore which subgroups have been more or less affected. These results can assist in the comprehension of these phenomena and allow the development of more specific strategies and targeted at the different needs of each context. In this sense, the aims of the study were to examine changes in the prevalence of overweight and obesity among students in Santa Catarina State from 2001 to 2011, as well as to verify if these changes differ according to age group, area of residence, and gross monthly household income.

\section{Methods}

\section{Sampling}

This study analyzes secondary data from two cross-sectional surveys (2001 and 2011) of the "Health risk behaviors project (CompAC) in youth of the Santa Catarina State, Brazil", with a representative sample of high-school students (15-19-year-old) from public schools of Santa Catarina State, Brazil. This research used the procedures of sampling by conglomerates, considering as strata the geographic regions and its respective regional education management. The calculation of the number of schools required in each stratum was obtained applying the proportionality criterion. For the number of classes required, an average of 25 students per class was estimated in 2001. As this number of students per class did not reach the required sample, an average of $17 \mathrm{stu}-$ dents were considered for the 2011 survey. Whit this information, the probabilities of participation in the sample were obtained for the sample weight calculation and correction of the imbalance introduced by the adopted sampling plan.

The same statistical parameters for sample size calculation (prevalence of the phenomenon of $50 \%$, maximum error of $2 \%$, design effect of two, and addition of $25 \%$ to account for possible losses or refusals) were adopted in both surveys (resulting in an estimated sample size of 5,932 adolescents), as well as the research tools used. After the exclusion of ineligible students (out of the age range of 15-19 years) in both surveys (2001: $\mathrm{n}=380 ; 2011: \mathrm{n}=508$ ), it was observed that 55 of the 5,083 participants in the 2001 survey filled-out the questionnaire incorrectly (final sample of 5,028) and, of the 6,569 students in the 2011 survey, 40 had their information lost due to the same reason (final sample of 6,529). Additional information on the study methodology can be found on a previously published paper ${ }^{16}$.

Both surveys (2001 and 2011) followed ethical principles and were approved by the Ethics Committee on Human Research of the Federal University of Santa Catarina, Brazil. For students under the age of 18 , parents or legal guardians needed to give their consent for participation in the research, and passive informed consent was used ${ }^{16}$.

\section{Data collection}

A standardized questionnaire was applied. The reproducibility of the instrument ranged between 0.69 and 0.99 in 2001 and between 0.51 and 0.96 in $2011^{16}$. In the present study, we used self-reported measures of weight and height to calculate participants' body mass index (BMI). Nutritional status was calculated according to WHO cut-off points ${ }^{17}$ : normal weight: $<-2 S D$; overweight: >+1SD (equivalent to BMI $25 \mathrm{~kg} / \mathrm{m}^{2}$ at 19 years); obesity: $>+2 \mathrm{SD}$ (equivalent to BMI $30 \mathrm{~kg} / \mathrm{m}^{2}$ at 19 years).

Sociodemographic strata were: age (15-16 and 17-19 years old); area of residence (rural and urban), and gross monthly household income (until five minimum wages and six or 
more minimum wages earned by all household members). In 2001, the minimum wage in Brazil was R\$180.00 (US\$71.71) and in 2011 it was R\$545.00 (US\$340.63).

\section{Statistical analysis}

Descriptive statistics was used to present the prevalence of overweight and obesity among adolescents, stratified by gender, in the two surveys (2001 and 2011) and their respective 95\% confidence interval $(95 \% \mathrm{CI})$. Multinomial logistic regression was used and nutritional status was the outcome (normal weight was the reference category) and the surveys (2001 and 2011) were the exposure. The adjusted analysis was performed in the following manner: a) age subgroup: adjustment for gross monthly household income and area of residence; b) area of residence subgroup: adjustment for age group and gross monthly household income; c) gross monthly household income subgroup: adjustment for age group and area of residence. Values were expressed as odds ratios (OR) and 95\%CI to verify the association between the survey year (2001 vs. 2011) and the outcomes (overweight and obesity). This decision was justified by the trends investigated in other studies ${ }^{8,9}$.

With the aim of verifying the average outcome variation over the years, we estimated annual change rates. Therefore, for each outcome, we calculated the difference (subtraction) of the prevalence rates from 2011 and 2001. Then, the result obtained was divided by ten (corresponding to the number of years between the two surveys: 2001 to 2011$)^{18,19}$. It should be highlighted that these calculations were made for each of the subgroups considered in the present study (age group, area of residence, and gross monthly household income).

The value corresponding to the relative outcome change (percent change) over ten years was calculated as the difference between the prevalence of each outcome referent to 2011 and 2001. Next, the value found was divided by the prevalence of 2001 and multiplied by 100, being represented by the term "delta".

Data analyses were performed using Stata ${ }^{\circledR}$ Standard Edition, version 13.0 for Microsoft ${ }^{\circledR}$ Windows $^{\mathrm{TM}}$ (StataCorp LP, USA) and in Microsoft Office Excel version 2013. We considered the methodology for analysis of complex data, adding the prefix "svyset" to incorporate strata, clusters, and sampling weights. For all tests, the level of significance was $5 \%$.

\section{Results}

Among the 5,028 students that filled out the questionnaire, a total of 4,924 answered the questions relative to weight and height in 2001 (response rate $=97.9 \%$ ), and the 6,529 total students, 6,366 answered these questions in 2011 (response rate $=97.5 \%)$. Most of the study participants were females $(59,4 \%$ in $2001 ; 55,5 \%$ in 2011$)$, aged between 15 and 16 years-old (51,2\% in 2001; 58,8\% in 2011), lived in urban areas $(79,6 \%$ in 2001 ; $76,3 \%$ in 2011 ), and had a gross monthly household income up to five minimum wages $(71,5 \%$ in $2001 ; 82,5 \%$ in 2011 ). In 2001, the prevalence of overweight and obesity among the students was $10.9 \%$ (95\%CI: 9.9- 12.0) and 1.6\% (95\%CI: 1.2- 2.1), respectively. In 2011 survey, $15.7 \%$ (95\%CI: 14.7- 16.7) and 3.8\% (95\%CI: 3.2- 4.4), respectively.

Figure 1 presents the prevalence of overweight and obesity among the students, stratified by sex, in the surveys of 2001 and 2011. Among boys, there was an increase in the prevalence of overweight (2001: 14.4\% 95\%CI: 12,7-16,4; 2011: 19.0\% 95\%CI: 17.3-20.8) and obesity (2001: 2.3\% 95\%CI: 1.5-3.3; 2011: 3.7\% 95\%CI: 3.7-5.9). Among girls, there was also an increase in the prevalence of overweight (2001: $8.6 \%$ 95\%CI: 7.3-10.0; 2011: 13.3\% 95\%CI: 12.0-14.8) and obesity (2001: 1.1\% 95\%CI: 0,7-1.7; 2011: 3.1\% 95\%CI: 2,5-3,9).

Table 1 presents the trend of overweight and obesity among boys over a decade, according to sociodemographic strata. Delta values, representing percent change in outcomes over the years, ranged from $-7.0 \%$ to $45.4 \%$ for overweight and $97.6 \%$ to $363 \%$ for obesity. Annual rates, showing the percent change per year, were of $-0.01 \%$ to $0.62 \%$ for overweight and of $0.08 \%$ to $0.27 \%$ for obesity. In the 2011 survey, compared to the 2001 survey, the odds of being overweight and obese were higher among younger (ORobesity: 4.52 95\%CI: 1.30-15.71) and older boys (ORoverweight: 1.61 95\%CI: 1.16-2.23 and ORobesity: 2.54 95\%CI: 1.20-5.38), and among those living in urban areas (ORoverweight: 1.55 95\%CI: $1.15-2.08$ and ORobesity: 3.21 95\%CI: 1.66-6.23) and with high family income (ORoverweight: 1.63 95\%CI: 1.20-2.22 and ORobesity: 3.51 95\%CI: 1.73-7.12).

Table 2 presents the trend of overweight and obesity among girls over a decade, according to sociodemographic strata. Delta values, representing percent change in outcomes over the years, ranged from $56.3 \%$ to $81.8 \%$ for overweight and 

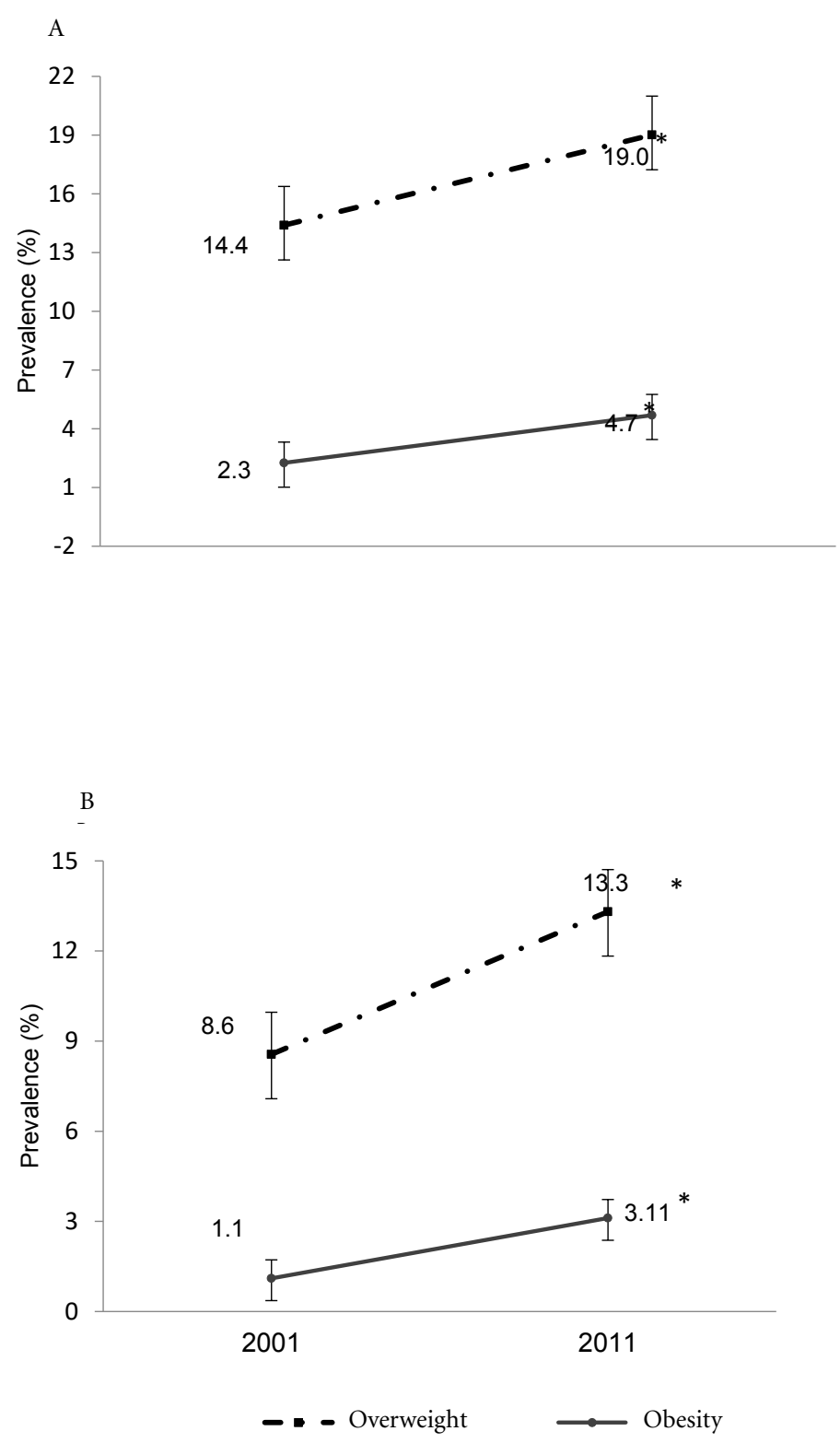

Figure. 1. Prevalence of overweight and obesity among boys (A) and girls (B) from public high schools of the Santa Catarina State, Brazil.

*based on the $95 \%$ confidence interval

$4.2 \%$ to $386.4 \%$ for obesity. Annual rates, showing the percent change per year, were of $0.37 \%$ to $0.50 \%$ for overweight and of $0.06 \%$ to $0.27 \%$ for obesity. We observed that in the 2011 survey, compared to the 2001 survey, the odds of being overweight and obese were higher among young- er (ORoverweight: 2.06; 95\%CI: 1.41-3.02 and ORobesity: 3.05; 95\%CI: 1.12-8.32) and older girls (ORoverweight: 1.89; 95\%CI: 1.33-2.68 and ORobesity: 3.17; 95\%CI: 1.54-6.56), among those living in rural areas (ORoverweight: 2.14 95\%CI: 1.03-4.43) and urban areas (ORover- 
Table 1. Prevalence, delta, and annual change in overweight and obesity prevalence and their respective odds ratios by age, area of residence, and gross monthly household income, among boys in Santa Catarina State between 2001 and 2011 (Santa Catarina, 2000 and 2010).

\begin{tabular}{|c|c|c|c|c|c|}
\hline \multirow{2}{*}{ Variables } & \multicolumn{2}{|c|}{$\%(95 \% \mathrm{CI})$} & \multirow{2}{*}{$\begin{array}{c}\text { Delta } \\
(\%)\end{array}$} & \multirow{2}{*}{$\begin{array}{c}\text { Annual } \\
\text { change (\%) }\end{array}$} & \multirow[t]{2}{*}{$\mathrm{OR}^{\star}(95 \% \mathrm{CI})$} \\
\hline & 2001 & 2011 & & & \\
\hline \multicolumn{6}{|l|}{ Age } \\
\hline \multicolumn{6}{|l|}{15 and 16 years } \\
\hline Overweight & $15,6(12,7 ; 18,9)$ & $20,4(18,3 ; 2,7)$ & 31 & 0,48 & $1,47(1,12 ; 1,92)$ \\
\hline Obesity & $3,3(1,9 ; 5,8)$ & $5,1(4,0 ; 6,5)$ & 55 & 0,18 & $1,59(0,85 ; 2,97)$ \\
\hline \multicolumn{6}{|l|}{17 to 19 years } \\
\hline Overweight & $13,5(11,3 ; 16,1)$ & $17,1(14,6 ; 19,9)$ & 27 & 0,36 & $1,40(1,04 ; 1,88)$ \\
\hline Obesity & $1,4(0,9 ; 2,4)$ & $4,1(2,8 ; 5,9)$ & 193 & 0,27 & $2,93(1,54 ; 5,58)$ \\
\hline \multicolumn{6}{|l|}{ Area of residence } \\
\hline \multicolumn{6}{|l|}{ Urban } \\
\hline Overweight & $13,4(11,3 ; 15,8)$ & $19,6(17,6 ; 21,7)$ & 46 & 0,62 & $1,61(1,27 ; 2,03)$ \\
\hline Obesity & $2,5(1,6 ; 3,8)$ & $4,9(3,7 ; 6,4)$ & 96 & 0,24 & $2,03(1,19 ; 3,48)$ \\
\hline \multicolumn{6}{|l|}{ Rural } \\
\hline Overweight & $17,6(14,2 ; 21,6)$ & $16,4(13,8 ; 19,4)$ & -7 & $-0,12$ & $0,92(0,67 ; 1,28)$ \\
\hline Obesity & $1,5(0,7 ; 3,1)$ & $3,9(2,4 ; 6,3)$ & 160 & 0,24 & $2,05(0,84 ; 5,03)$ \\
\hline \multicolumn{6}{|c|}{$\begin{array}{l}\text { Gross monthly household } \\
\text { income }\end{array}$} \\
\hline \multicolumn{6}{|c|}{ Low } \\
\hline Overweight & $16,5(13,0 ; 20,7)$ & $16,4(13,8 ; 19,4)$ & -1 & $-0,01$ & $1,07(0,76 ; 1,52)$ \\
\hline Obesity & $2,5(1,2 ; 5,1)$ & $3,9(2,4 ; 6,2)$ & 56 & 0,14 & $1,16(0,44 ; 3,04)$ \\
\hline \multicolumn{6}{|l|}{ High } \\
\hline Overweight & $13,5(11,3 ; 16,2)$ & $18,8(15,8 ; 22,2)$ & 39 & 0,53 & $1,59(1,23 ; 2,08)$ \\
\hline Obesity & $2,2(1,4 ; 3,6)$ & $3,0(1,9 ; 4,7)$ & 36 & 0,08 & $2,39(1,34 ; 4,24)$ \\
\hline
\end{tabular}

weight: 1.93 ; 95\%CI: $1.45-2.58$ and ORobesity: 3.48; 95\%CI: 1.92-6.31), and among those with low family income (ORoverweight: 1.77 95\%CI: 1.16-2.70), and high family income (ORoverweight: 2.07 95\%CI: 1.47-2.91 and ORobesity: 5.96; 95\%CI: 2.59-13.71).

\section{Discussion}

The present study showed that among both boys and girls, there was an increase in the prevalence of overweight and obesity from 2001 to 2011. In general, the odds of being overweight and obese were higher, in 2011 compared 2001, among those boys living in urban areas and with high family income. Regarding girls, those from 2011 (compared to 2001), showed a higher odds of being overweight and obese among those living in rural and urban areas, with low and high family income.

Studies shows evidences about global increase in the prevalence of overweight and obesity in adolescents $^{2,4,20}$. In Brazil, the National Household Budget Survey also identified an increased prevalence of obesity among boys and girls in a period of 34 years, especially in the South Region (boys: $0.6 \%$ to $7.7 \%$ and girls: $1.0 \%$ to $5.4 \%)^{7}$.

In Mozambique, South Africa, a positive secular trend was observed between 1992 and 2012 both for overweight (boys: from $0.8 \%$ to $5.0 \%$; girls: from $5.1 \%$ to $11.2 \%$ ) and obesity (boys: from $0.8 \%$ to $6.0 \%$; girls: from $1.8 \%$ to $9.1 \%)^{2}$.

In Guangzhou (China), between 2007 to 2011, the prevalence of overweight increased in boys from $10.5 \%$ to $12.9 \%$ and in girls from $5.9 \%$ to $7.0 \%$. In the same period, obesity increased from $4.2 \%$ to $5.7 \%$ and from $2.1 \%$ to $2.7 \%$ among boys and girls, respectively ${ }^{20}$. There 
Table 2. Prevalence, delta, and annual change in overweight and obesity prevalence and their respective odds ratios by age, area of residence, and gross monthly household income, among girls in Santa Catarina State between 2001 and 2011 (Santa Catarina, 2000 and 2010).

\begin{tabular}{|c|c|c|c|c|c|}
\hline \multirow{2}{*}{ Variables } & \multicolumn{2}{|c|}{$\%(95 \% \mathrm{CI})$} & \multirow{2}{*}{$\begin{array}{c}\text { Delta } \\
(\%)\end{array}$} & \multirow{2}{*}{$\begin{array}{c}\text { Annual } \\
\text { change (\%) }\end{array}$} & \multirow[t]{2}{*}{$\mathrm{OR}^{\star}(95 \% \mathrm{CI})$} \\
\hline & 2001 & 2011 & & & \\
\hline \multicolumn{6}{|l|}{ Age } \\
\hline \multicolumn{6}{|l|}{15 and 16 years } \\
\hline Overweight & $8,0(6,5 ; 9,8)$ & $13,0(11,2 ; 15,0)$ & 63 & 0,50 & $1,79(1,36 ; 2,34)$ \\
\hline Obesity & $0,9(0,5 ; 1,7)$ & $2,6(2,0 ; 3,4)$ & 189 & 0,17 & $3,24(1,51 ; 6,93)$ \\
\hline \multicolumn{6}{|l|}{17 to 19 years } \\
\hline Overweight & $9,1(7,4 ; 11,2)$ & $13,9(12,0 ; 16,1)$ & 53 & 0,48 & $1,61(1,20 ; 2,15)$ \\
\hline Obesity & $1,3(0,8 ; 2,2)$ & $4,0(2,8 ; 5,5)$ & 208 & 0,27 & $3,50(1,81 ; 6,78)$ \\
\hline \multicolumn{6}{|l|}{ Area of residence } \\
\hline \multicolumn{6}{|l|}{ Urban } \\
\hline Overweight & $8,6(7,3 ; 10,0)$ & $13,5(12,0 ; 15,2)$ & 57 & 0,49 & $1,72(1,38 ; 2,14)$ \\
\hline Obesity & $1,2(0,8 ; 1,8)$ & $3,5(2,8 ; 4,5)$ & 192 & 0,23 & $3,57(2,14 ; 5,94)$ \\
\hline \multicolumn{6}{|l|}{ Rural } \\
\hline Overweight & $8,7(6,1 ; 12,2)$ & $12,4(10,3 ; 14,9)$ & 43 & 0,37 & $1,57(0,98 ; 2,51)$ \\
\hline Obesity & $0,7(0,2 ; 3,3)$ & $1,5(0,7 ; 2,9)$ & 114 & 0,08 & $2,13(0,31 ; 14,30)$ \\
\hline \multicolumn{6}{|c|}{ Gross monthly household income } \\
\hline \multicolumn{6}{|c|}{ Low } \\
\hline Overweight & $9,1(7,3 ; 11,3)$ & $13,9(11,9 ; 16,2)$ & 53 & 0,48 & $1,68(1,23 ; 2,31)$ \\
\hline Obesity & $2,0(1,0 ; 3,7)$ & $2,6(1,8 ; 3,8)$ & 30 & 0,06 & $1,50(1,69 ; 3,27)$ \\
\hline \multicolumn{6}{|l|}{ High } \\
\hline Overweight & $8,2(6,7 ; 10,1)$ & $12,7(11,2 ; 14,4)$ & 55 & 0,45 & $1,69(1,31 ; 2,19)$ \\
\hline Obesity & $0,6(0,3 ; 1,1)$ & $3,3(2,3 ; 4,7)$ & 450 & 0,27 & $7,06(3,38 ; 14,72)$ \\
\hline
\end{tabular}

was also an increase in overweight and obesity among Mexican adolescents, from 11.1\% in 1998 to $35.8 \%$ in $2012^{21}$.

In fact, a systematic review conducted by Wang and $\mathrm{Lim}^{8}$ describing the prevalence of overweight and obesity worldwide states that, over the last two decades, the increase in the prevalence of these outcomes has been occurring especially in countries that experienced rapid economic and social transitions, like China, Mexico, and Brazil. The authors of the systematic review affirm that a considerable number of studies point to the important contribution to the current scenario of globalization and its resulting change in society, environments, and individual behavioral patterns. Adding to this point, there are other factors such as economic growth, modernization, urbanization, and food market globalization ${ }^{4}$. This social and cultural transition results in an increase of fast-food consumption and a reduction in traditional and healthier meals. Also, low levels of physical activity and high time spent in sedentary behavior are factors that might be related to the high prevalence of overweight and obesity among adolescents ${ }^{2,22}$.

On the other hand, it has been observed in Australia $^{23}$, Canada ${ }^{24}$, and some European countries a trend of stability or even decrease in the prevalence of overweight and obesity among both boys and girls ${ }^{22,25}$, Authors' arguments to explain this scenario are based on increased media attention $^{26}$, intervention programmes ${ }^{22}$ and increased parental awareness ${ }^{25}$ of the consequences of obesity. However, it is necessary more attention to the fact that children from lower socio-economic strata have not benefited from this trend ${ }^{25}$.

The literature shows trends regarding the overweight and obesity in the overall population, however, our findings, highlights the importance of examining trends in overweight and obesity taking into account some characteristics. In general, we have observed that in 2011 there 
was an increase in the odds of being overweight and obese in most of the subgroups, however, we emphasize that, the odds of the outcomes differ according to the subgroup investigated.

Among the both younger and older age groups, the odds of being overweight were higher from 2011, compared to 2001. In relation to obesity, odds were higher only for girls. It is observed that, even considering subgroups with different ages, the new generation has significantly lower physical activity levels, significantly higher screen time and changes in dietary intake, a trend that occur concomitantly with the increase in obesity ${ }^{3,27}$.

The prevalence of overweight and obesity presents a distinct behavior in rural and urban areas, being influenced by the culture and the level of country development ${ }^{28,29}$. Over a decade, we verified that the odds of being overweight and obese were higher in adolescents living in urban areas only, which was verified in previously studies, especially in developing countries ${ }^{20,30}$. According to a meta-analysis conducted by Yu et al. ${ }^{31}$, from 1991 to 2010 the prevalence of overweight and obesity among the Chinese increased more in urban areas (8.2\%; CI: $6.4 \%, 9.9 \%)$ than in rural areas (5.3\%; CI: $4.2 \%, 6.3 \%)$.

These findings might be explained by the increased access to ultra-processed foods and energy-dense foods and reduced intake of fruits and vegetables, as well as the lower levels of physical activity among adolescents living in urban areas. Moreover, families living in urban areas usually have more televisions and computers and prefer to use the car instead of walking or using a bicy$\mathrm{cle}^{31,32}$, increasing the risk of hypokinetic diseases such as obesity. Conversely, families living in rural areas still tend to engage in manual labor, use more active transportation and eat more fruits and vegetables compared to those living in urban $\operatorname{areas}^{20,30,33}$.

Nonetheless, special attention should be given to girls living in rural areas, since they presented higher odds of being overweight and obesity in 2011. A possible hypothesis is that girls, compared to boys, might be starting to become more susceptible to lifestyle changes accompanying modernization and rural development, resulting in social, cultural, and economic transformations, including changes in eating patterns ${ }^{34}$.

For girls, income does not seem to exert as much influence as there was a greater chance of being overweight and obese in 2011 for the low- and high-income group. We highlight that, for both genders in 2011, adolescents with higher gross monthly household income had higher odds of being overweight and obese compared to 2001. Similar results for the family income pattern were observed in other studies ${ }^{27,30}$. In Brazil, between 1974 and 2009, obesity prevalence increased (from $0.1 \%$ to $2.1 \%$ ) among adolescents of both genders across all income strata, but with greater magnitude among those with higher income (from $1.2 \%$ to $9.2 \%)^{35}$.

With regards to family income, the level of development of the country has to be considered. In Canada ${ }^{24}$, United States ${ }^{36}$, Australia ${ }^{37}$ and Europe ${ }^{38}$ for instance, the prevalence and the odds of obesity are increasing more among low-income adolescents over the years. In California, United States, for instance, the income disparities showed that the prevalence in those from low income raised more than double, when compared with those from higher income (2001: $17 \%$ vs $10 \%$ and $2007: 23 \%$ vs $8 \%$, respectively) ${ }^{39}$. In these countries, low-income families have had their purchasing power increased, having more access to video games, computer, and ultra-processed foods ${ }^{40,41}$, in addition, high-income adolescents have more options for caring for and preventing obesity ${ }^{39}$. However, in emerging countries like India, the prevalence of overweight and obesity increased significantly (2006-2009) among high-income adolescents ${ }^{30}$. These differences point to a possible reduction in economic disparity associated with the development and increase in obesity prevalence.

Obesity is complex because it is influenced by physical, socio-cultural and environmental issues. Therefore, it is fundamental to understand the characteristics of the population that present the greatest risks to be able to intervene in the best way. Thus, from the trend analysis of overweight and obesity in children and adolescents, in different strata, it is possible to direct future public policies for the subpopulations that present greater chances of developing this unfavorable aspect to health, such as people that live in urban areas and with high gross monthly household income.

Our study has some limitations, such as the minimum wage difference between the two surveys; also, it is important to emphasize that the variable gross monthly household income was reported by the students, and the variability between those values and the real values is unknown. The area of residence was also reported by the adolescents, resulting in possible mistakes due to the lack of knowledge about the criteria that should be used to classify area of residence. The use of self-reported weight and height to cal- 
culate the BMI of the adolescents can be considered another limitation, because it may result in response bias, since girls tend to underestimate their body mass while boys tend to overestimate it, due to cultural patterns. However, this measure shows validity when used with children and adolescent $\mathrm{s}^{42,43}$. Besides that, self-reported family income also can be considered a limitation, because it is possible to be difficult for the adolescent to know the exact information. On the other hand, the high response rate in both surveys (2001 and 2011) and the representativeness of the sample are positive aspects, as well as the fact that the study has shown differences between overweight and obesity stratified by gender and discussing other sociodemographic factors such as area of residence and gross monthly household income.

\section{Conclusions}

We conclude that there was an increase in the prevalence of overweight and obesity among students in Santa Catarina State over a decade. Among the sociodemographic factors investigated, boys and girls living in urban areas and with high gross monthly household income presented, in the 2011 survey, higher odds of being overweight and obese compared to those in the 2001 survey. This information may foster the development of current policies, as well as the development of future intervention programs to prevent and decrease overweight and obesity in adolescents. Since the trends were different in the subgroups studied, specific interventions for each context are essential to increase the effectiveness of actions.

\section{Collaborations}

PC Santos, KS Silva, JA Silva, CES Santos, GF Del Duca, AS Lopes e MV Nahas have participated in the execution of the study and have read and approved the final version of the manuscript.

\section{Acknowledgements}

To the Secretary of Education of the state of Santa Catarina for authorizing the realization of the COMPAC project in both years; The managers of the Regional Education Offices, the administrators of the schools drawn, the teachers who kindly gave up their class and all the students who participated in this study. Finally, we thank all the members of the Research Group on Physical Activity and Health that participated in the data collection. 


\section{References}

1. Ma L, Mai J, Jing J, Liu Z, Zhu Y, Jin Y, Chen Y. Empirical change in the prevalence of overweight and obesity in adolescents from 2007 to 2011 in Guangzhou, China. Eur J Pediatr 2014; 173(6):787-791.

2. Santos FK, Maia JA, Gomes TNQF, Daca T, Madeira A, Katzmarzyk PT, Prista A. Secular trends in growth and nutritional status of Mozambican school-aged children and adolescents. PloS one 2014; 9(12):e114068.

3. Sigmund E, Sigmundova D, Badura P, Kalman M, Hamrik Z, Hamrik Z, Pavelka J. Temporal Trends in Overweight and Obesity, Physical Activity and Screen Time among Czech Adolescents from 2002 to 2014: A National Health Behaviour in School-Aged Children Study. Int J Environ Res Public Health 2015; 12(9):11848-11868.

4. Ng M, Fleming T, Robinson M, Thomson B, Graetz N, Margono C, Mullany EC, Biryukov S, Abbafati C, Abera SF, Abraham JP, Abu-Rmeileh, NME, Achoki Y,Albuhairan FS, Alemu ZA, Alfonso R, Ali MK, Guzman NA, Ammar W, Anwari P, Banerjee A, Barquera S, Basu S, Bennett DA, Bhutta Z, Blore J, Cabral N, Nonato IC, Chang JC, Chowdhury R, Courville KJ, Criqui MH, Cundiff DK, Dabhadkar KC, Dandona L, Davis A, Dayama A, Dharmaratne SD, Ding EL, Durrani AM, Esteghamatu A, Farzadfar F, Fay DF, Feigin VL, Flaxman A, Forouzanfar MH, Goto A, Green MA, Gupta R, Hafezi-Nejad N, Hankey GJ, Harewood HC, Havmoeller R, Hay S, Hernandez L, Husseini A, Idrisoy BT, Ilkeda N, Islami F, Jahangir E, Jassal SK, Jee SH, Jeffeys M, Jonas JB, Kabagambe EKK, Khalifa SEAH, Kengne AP, Khader YS, Khang YH, Kim D, Kimokoti RW, Kinge JM, Kokubo Y, Kosen S, Kwan G, Lai T, Leinsalu M, Li Y, Liang X, Liu S, Logroscino G, Lotufo PA, Lu Y, Ma J, Mainoo NK, Mensah GA, Merriman TR, Mokdad AH, Moschandreas J, Naghavi M, Naheed A, Nand D, Narayan KMV, Nelson EL, Neuhouser ML, Nisar MI, Ohkubo T, Oti SO, Pedroza A, Prabhakaran D, Roy N, Sampson U, Seo H, Sepanlou SG, Shibuya K, Shiri R, Shiue I, Singh GM, Singh JA, Skirbekk V, Stapelberg NJC, Strua L, Sykes BL, Tobias M, Tran BX, Transande L, Toyoshima H, Vijver SV, Vasankari TJ, Verrman JL, Velasquez-Melendez G, Vlassov VV, Vollset SE, Vos T, Wang C, Wang XR, Weiderpass E, Werdecker A, Wright J, Yang YC, Yatsuya H, Yoon J, Yoon S, Zhao, Zhou M, Zhu S, Lopez AD, Murray CJL, Gakidou E. Global, regional, and national prevalence of overweight and obesity in children and adults during 1980-2013: a systematic analysis for the Global Burden of Disease Study 2013. Lancet 2014; 384(9945):766-781.

5. Bibiloni Mdel M, Pons A, Tur JA. Prevalence of overweight and obesity in adolescents: a systematic review. ISRN Obes 2013; 2013:392747.

6. Sun H, MA Y, Han D, Pan C-W, Xu Y. Prevalence and Trends in Obesity among China's Children and Adolescents, 1985-2010. PloS one 2014; 9(8):e105469.

7. Instituto Brasileiro de Geografia e Estatística (IBGE). Antropometria e Estado Nutricional de Crianças, Adolescentes e Adultos no Brasil. Rio de Janeiro: IBGE; 2010.

8. Wang Y, Lim H. The global childhood obesity epidemic and the association between socio-economic status and childhood obesity. Int Rev Psychiatry 2012; 24(3):176-188.
9. Olds TS, Tomkinson GR, Ferrar KE, Maher CA Trends in the prevalence of childhood overweight and obesity in Australia between 1985 and 2008. Int J Obes (Lond) 2010; 34(1):57-66.

10. Wang LY, Chyen D, Lee S, Lowry R. The association between body mass index in adolescence and obesity in adulthood. J Adolesc Health 2008; 42(5):512-518.

11. The NS, Suchindran C, North KE, Popkin BM, Gordon-Larsen P. Association of adolescent obesity with risk of severe obesity in adulthood. JAMA 2010; 304(18):2042-2047.

12. Reilly JJ, Kelly J. Long-term impact of overweight and obesity in childhood and adolescence on morbidity and premature mortality in adulthood: systematic review. Int J Obes (Lond) 2011; 35(7):891-898.

13. Lien N, Henriksen HB, Nymoen LL, Wind M, Klepp KI. Availability of data assessing the prevalence and trends of overweight and obesity among European adolescents. Public Health Nutr 2010; 13(10A):16801687.

14. Pinho L, Botelho ACC, Caldeira AP. Fatores associados ao excesso de peso em adolescentes de escolas públicas no norte de Minas Gerais. Rev Paul Pediatr 2014; 32(2):237-243.

15. Xavier MO, Bielleman RM, Maciel FV, Neutzling MB, Gigante DP. Temporal variation in overweight and obesity in adolescents from a private school of Southern Brazil. Rev Bras Ativ Fis Saude 2012; 19(1):74-85.

16. Silva KS, Lopes AS, Hoefelmann LP, Cabral LGA, Bem MFL, Barros MVG, Nahas MV. Projeto COMPAC (comportamentos dos adolescentes catarinenses):aspectos metodológicos, operacionais e éticos. Rev Bras Cineantropometria e Desempenho Hum 2013; 15(1):115.

17. World Health Organization (WHO). WHO Reference 2007. Growth reference data for 5-19 years. [cited 2017 Oct 2]. Available from: http://www.who.int/growthref/en/

18. Booth ML, Dobbins T, Okely AD, Denney-Wilson E, Hardy LL. Trends in the Prevalence of Overweight and Obesity among Young Australians, 1985, 1997, and 2004. Obesity (Silver Spring) 2007; 15(5):1080-1095.

19. Silva KS, Lopes AS, Dumith SC, Garcia, LM, Bezerra J, Nahas MV. Changes in television viewing and computers/videogames use among high school students in Southern Brazil between 2001 and 2011. Int J Public Health 2014; 59(1):77-86.

20. Song Y, Wang HJ, Ma J, Wang Z. Secular trends of obesity prevalence in urban Chinese children from 1985 to 2010: gender disparity. PLoS One 2013; 8(1):e53069.

21. Hernandez-Cordero S, Cuevas-Nasu L, Moran-Ruan MC, Mendez-Gomez Humaran I, Avila-Arcos MA, Rivera-Dommarco JA. Overweight and obesity in Mexican children and adolescents during the last 25 years. Nutr Diabetes 2017; 7(3):e247.

22. Kowal M, Kryst L, Woronkowicz A, Sobiecki J. Longterm changes in body composition and prevalence of overweight and obesity in girls (aged 3-18 years) from Krakow (Poland) from 1983, 2000 and 2010. Ann Hum Biol 2014; 41(5):415-427.

23. Ho NS, Olds T, Schranz N, Maher C. Secular trends in the prevalence of childhood overweight and obesity across Australian states: A meta-analysis. J Sci Med Sport 2017; 20(5):480-488. 
24. Rao DP, Kropac E, Do MT, Roberts KC, Jayaraman GC. Childhood overweight and obesity trends in Canada. Health Promot Chronic Dis Prev Can 2016; 36(9):194-198.

25. Stamatakis E, Wardle J, Cole TJ. Childhood obesity and overweight prevalence trends in England: evidence for growing socioeconomic disparities. Int $J$ Obes (Lond) 2010; 34(1):41-47.

26. Aeberli I, Henschen I, Molinari L, Zimmermann MB. Stabilisation of the prevalence of childhood obesity in Switzerland. Swiss Med Wkly 2010; 15:140.

27. Su C, Zhang B, Wang YF, Jia XF, Xue H, Wang HJ. Epidemics of overweight and obesity among growing childhood in China between 1997 and 2009: Impact of Family Income, Dietary Intake, and Physical Activity Dynamics. Chin Med J 2015; 128(14):1879-1886.

28. Gokler ME, Bugrul N, Metintas S, Kalyoncu C. Adolescent obesity and associated cardiovascular risk factors of rural and urban life (Eskisehir, Turkey). Cent Eur J Public Health 2015; 23(1):20-25.

29. Johnson JA, Johnson AM. Urban-rural differences in childhood and adolescent obesity in the United States: a systematic review and meta-analysis. Child Obes 2015; 11(3):233-241.

30. Gupta DK, Shah P, Misra A, Bharadwaj S, Gulati S, Gupta N, Sharma R, Pandey RM, Goel K. Secular trends in prevalence of overweight and obesity from 2006 to 2009 in urban asian Indian adolescents aged 14-17 years. PLoS One 2011; 6(2):e17221.

31. Yu Z, Han S, Chu J, Xu Z, Zhu C, Guo X. Trends in overweight and obesity among children and adolescents in China from 1981 to 2010: a meta-analysis. PLoS One 2012; 7(12):e51949.

32. Wiggins S, Keats S. The rising cost of a healthy diet: changing relative prices of foods in high-income and emerging economies. London: Overseas Development Institute; 2015.

33. Nunes HMB, Borges TS, Hoehr CF, Tornquist D, Burgos MS, Gaya AR. Diferenças entre os hábitos alimentares associados ao excesso de peso de crianças e adolescentes da zona rural e urbana do município de Santa Cruz do Sul - RS. Cinergis 2014; 15(1):30-33.

34. Zanini RV, Muniz LC, Schneider BC, Tassitano RM, Feitosa WMN, Gonçalvez-Chica DA. Consumo diário de refrigerantes, doces e frituras em adolescentes do Nordeste brasileiro. Cien Saude Colet 2013; 18(12):3739-3750.

35. Farias Júnior JC, Mendonça G. Temporal trend in overweight among adolescents in northeastern Brazil. Arch Endocrinol Metab 2016; 60(1):21-28.
36. Watts AW, Mason SM, Loth K, Larson N, Neumark-Sztainer D. Socioeconomic differences in overweight and weight-related behaviors across adolescence and young adulthood: 10-year longitudinal findings from Project EAT. Prev Med 2016; 87:194-199.

37. Hardy LL, Mihrshahi S, Gale J, Drayton BA, Bauman A, Mitchell J. 30-year trends in overweight, obesity and waist-to-height ratio by socioeconomic status in Australian children, 1985 to 2015. Int J Obes (Lond) 2017; 41(1):76-82.

38. Knai C, Lobstein T, Darmon N, Rutter H, McKee M. Socioeconomic patterning of childhood overweight status in Europe. Int J Environ Res Public Health. 2012; 9(4):1472-1489.

39. Babey SH, Hastert TA, Wolstein J, Diamant AL. Income disparities in obesity trends among California adolescents. Am J Public Health 2010; 100(11):21492155.

40. Wang Y, Zhang Q. Are American children and adolescents of low socioeconomic status at increased risk of obesity? Changes in the association between overweight and family income between 1971 and 2002. Am J Clin Nutr 2006; 84(4):707-716.

41. Kautiainen S, Koivisto AM, Koivusilta L, Lintonen T, Virtanen SM, Rimpela A. Sociodemographic factors and a secular trend of adolescent overweight in Finland. Int J Pediatr Obes 2009; 4(4):360-370.

42. Chan NP, Choi KC, Nelson EA, Sung RY, Chan JC, Kong AP. Self-reported body weight and height: an assessment tool for identifying children with overweight/obesity status and cardiometabolic risk factors clustering. Matern Child Health J 2013; 17(2):282-291.

43. Farias Júnior JC. Validade das medidas auto-referidas de peso e estatura para o diagnóstico do estado nutricional de adolescentes. Rev. Bras. Saúde Matern. Infant 2007; 7(2):167-174.

Artigo apresentado em 06/08/2017

Aprovado em 09/02/2018

Versão final apresentada em 11/02/2018 
ERRATA ERRATUM

p. 3338,

onde se lê:

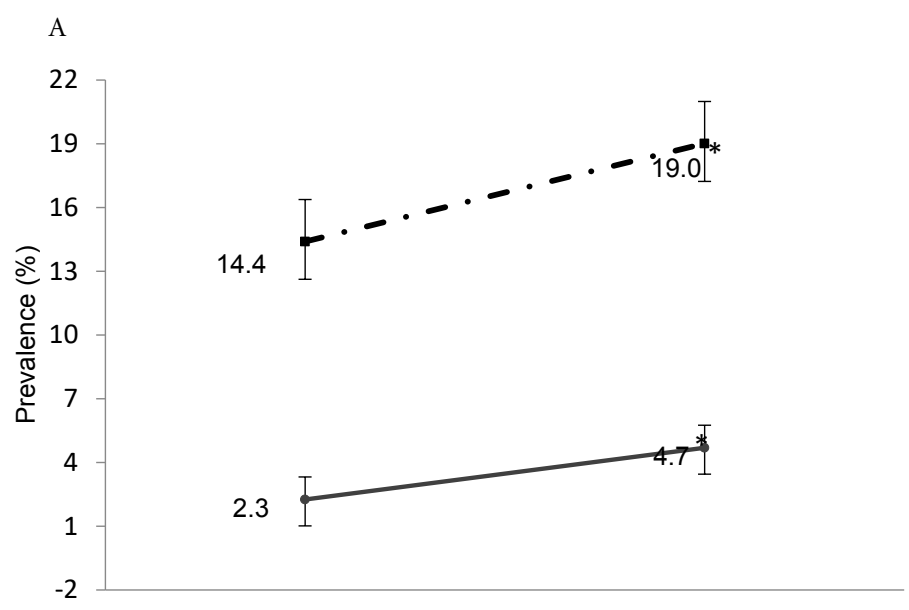

B

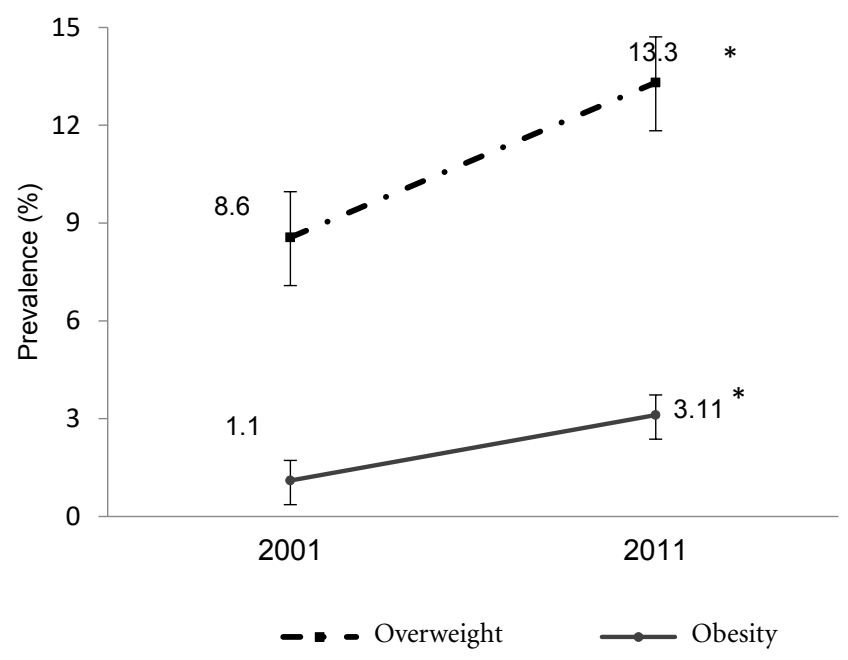

Figure. 1. Prevalence of overweight and obesity among boys (A) and girls (B) from public high schools of the Santa Catarina State, Brazil.

*based on the $95 \%$ confidence interval 


\section{leia-se:}
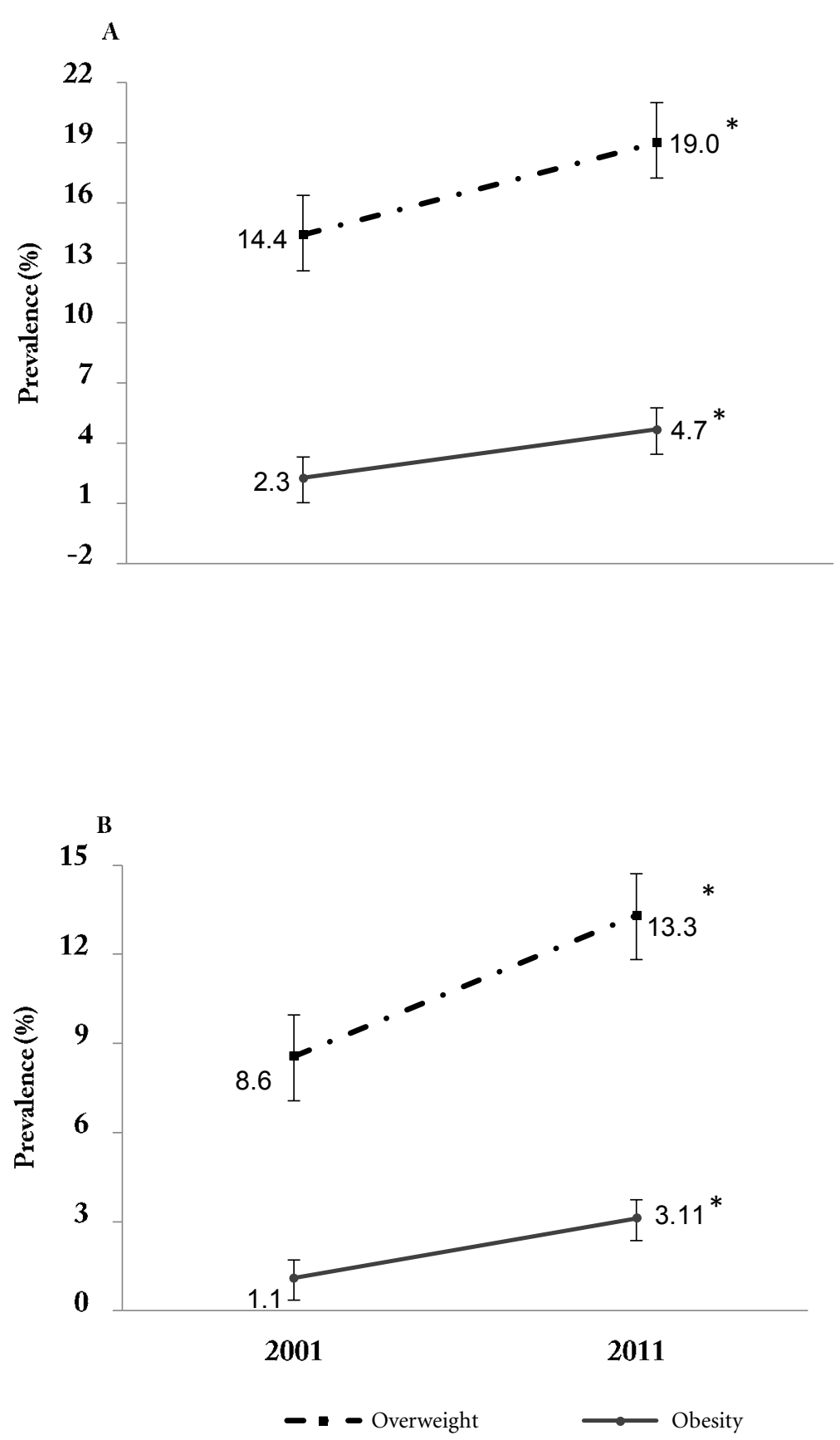

Figure. 1. Prevalence of overweight and obesity among boys (A) and girls (B) from public high schools of the Santa Catarina State, Brazil.

*based on the $95 \%$ confidence interval 